\title{
The Wnt/Frizzled pathway as a therapeutic target for cardiac hypertrophy: where do we stand
}

Citation for published version (APA):

ter Horst, P., Smits, J. F. M., \& Blankesteijn, W. M. (2012). The Wnt/Frizzled pathway as a therapeutic target for cardiac hypertrophy: where do we stand. Acta Physiologica, 204(1), 110-117. https://doi.org/10.1111/j.1748-1716.2011.02309.x

Document status and date:

Published: 01/01/2012

DOI:

10.1111/j.1748-1716.2011.02309.x

Document Version:

Publisher's PDF, also known as Version of record

Document license:

Taverne

Please check the document version of this publication:

- A submitted manuscript is the version of the article upon submission and before peer-review. There can be important differences between the submitted version and the official published version of record.

People interested in the research are advised to contact the author for the final version of the publication, or visit the DOI to the publisher's website.

- The final author version and the galley proof are versions of the publication after peer review.

- The final published version features the final layout of the paper including the volume, issue and page numbers.

Link to publication

\footnotetext{
General rights rights.

- You may freely distribute the URL identifying the publication in the public portal. please follow below link for the End User Agreement:

www.umlib.nl/taverne-license

Take down policy

If you believe that this document breaches copyright please contact us at:

repository@maastrichtuniversity.nl

providing details and we will investigate your claim.
}

Copyright and moral rights for the publications made accessible in the public portal are retained by the authors and/or other copyright owners and it is a condition of accessing publications that users recognise and abide by the legal requirements associated with these

- Users may download and print one copy of any publication from the public portal for the purpose of private study or research.

- You may not further distribute the material or use it for any profit-making activity or commercial gain

If the publication is distributed under the terms of Article $25 \mathrm{fa}$ of the Dutch Copyright Act, indicated by the "Taverne" license above, 


\title{
REVIEW \\ The Wnt/Frizzled pathway as a therapeutic target for cardiac hypertrophy: where do we stand?
}

\author{
P. ter Horst, J. F. M. Smits and W. M. Blankesteijn \\ Department of Pharmacology, Cardiovascular Research Institute Maastricht, Maastricht University, Maastricht, the Netherlands
}

Received 31 December 2010, revision requested 19 February 2011 ,

revision received 23 March $201 \mathrm{I}$, accepted 24 March 201 I

Correspondence: W. M.

Blankesteijn,

$\mathrm{PhD}$, Department of

Pharmacology, CARIM, PO Box

616, 6200MD Maastricht, the

Netherlands.

E-mail: wm.blankesteijn@

maastrichtuniversity.nl

\begin{abstract}
Cardiac hypertrophy is an enlargement of the heart muscle in response to wall stress. This hypertrophic response often leads to heart failure. In recent years, several studies have shown the involvement of Wnt signalling in hypertrophic growth. In this review, the role of Wnt signalling and the possibilities for therapeutic interventions are discussed. In healthy adult heart tissue, Wnt signalling is very low. However, under pathological condition such as hypertension, Wnt signalling is activated. In recent years, it has become clear that both $\beta$-catenin-dependent signalling and $\beta$-catenin-independent signalling are involved in hypertrophic growth. Several studies, both in vitro and in vivo, have shown that genetic interventions in Wnt signalling at different levels resulted in an attenuated or diminished hypertrophic response. Therefore, inhibition of Wnt signalling could provide a new therapeutic strategy for cardiac hypertrophy, but further research on the Wnts and Frizzleds involved in the different forms of cardiac hypertrophy will be needed to achieve this goal.
\end{abstract}

Keywords frizzled, heart, hypertrophy, therapy, Wnt.
Cardiac hypertrophy is an enlargement of the heart in response to an increase in wall stress. It is an adaptive response of the heart muscle to compensate for the decrease of cardiac output. It is characterized by an increase in cardiomyocyte size, increased protein synthesis, increased fibrosis and the upregulation of foetal genes that are normally activated in the developing heart, such as $\alpha$-actin, $\beta$-myosin heavy chain ( $\beta$-MHC), atrial natriuretic factor (ANF) and brain natriuretic peptide (BNP) (Oka et al. 2007, Rohini et al. 2010).

Several subtypes of hypertrophy can be distinguished. In the concentric form, the thickness of the cardiomyocytes is increased by the addition of parallel sarcomeres. Concentric hypertrophy is caused by pressure overload, which is seen in patients with hypertension or aortic stenosis. This form of cardiac hypertrophy results in an increase in wall thickness and a reduced left ventricular lumen. Eccentric hypertrophy is characterized by an elongation of the cardiomyocytes, resulting in ventricle dilation and thinning of the ventricle wall. Sarcomeres are added in series. This is caused by volume overload, for instance, due to valve defects or myocardial infarction (Frey et al. 2004, Ellery et al. 2006, Barry \& Townsend 2010). Although hypertrophy is at first a beneficial process, in the longer term, it progresses into decompensation, contractile dysfunction and heart failure. One to two percent of the population is affected by heart failure and the 5-year mortality is almost 50\% (Barry \& Townsend 2010).

Intensive exercise and pregnancy also lead to hypertrophy, but this enhances rather than deteriorates cardiac function. This form is called physiological hypertrophy, and does not lead to heart failure. Re-expression of foetal genes and fibrosis does not occur (Dorn 2007, McMullen \& Jennings 2007). The different forms of cardiac hypertrophy are shown in Figure 1. In this review, our focus will be on the pathological forms of cardiac hypertrophy. We will provide an overview of the literature and discuss the findings in a context of therapeutic potential of the pathway. 


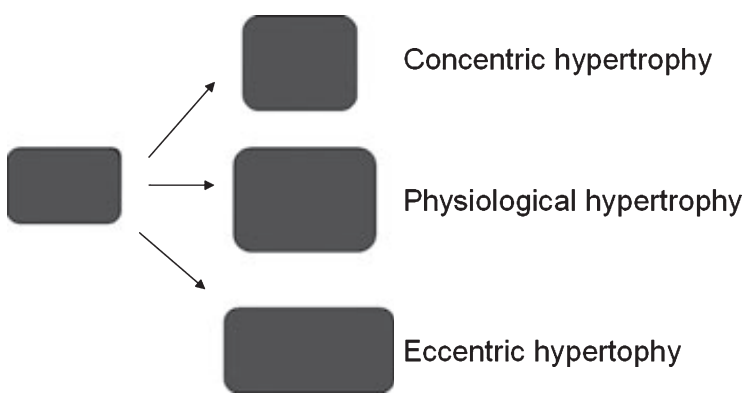

Figure I The different shapes of cardiomyocytes in concentric, eccentric and physiological hypertrophy.

\section{Signalling pathways}

Pathological hypertrophy is the result of the activation of several signalling pathways. Hypertrophic stimuli like angiotensin II (AngII), endothelin 1 (ET-1) and Phenylephrine (PE) can activate phospholipase (PLC), which hydrolyses $\mathrm{PIP}_{2}$ to inositol triphosphate $\left(\mathrm{IP}_{3}\right)$ and diacylglycerol (DAG). $\mathrm{IP}_{3}$ then releases intracellular $\mathrm{Ca}^{2+}$, which in turn activates calcineurin. Transcription factor binding sites for nuclear factor of activated T-cells (NFAT), Mef2, Gata, Nkx, Foxo, C/Ebp and Irf (Hannenhalli et al. 2006) have been found in human heart failure patients. NFAT is dephosphorylated by calcineurin and translocates to the nucleus, where it initiates the transcription of hypertrophic genes (Rohini et al. 2010). This leads to the expression of c-Jun, c-Fos and $\mathrm{c}-\mathrm{Myc}$ and foetal genes $\mathrm{ANF}, \mathrm{BNP}$ and $\beta$-MHC
(Usui et al. 2006). Interestingly, NFAT is phosphorylated by GSK3 $\beta$, a key component of $\beta$-catenin-mediated Wnt signalling, which will be discussed in more detail below.

Physiological hypertrophy, on the other hand, is mainly activated by growth factors such as insulin-like growth factor (IGF) and growth hormone (GH). Phosphoinositide $3^{\prime}$ kinase (PI3K) is activated via tyrosine kinase receptors. $\mathrm{PIP}_{2}$ is then phosphorylated to $\mathrm{PIP}_{3}$, which activates the kinase Akt by phosphorylation and the activated Akt causes the transcription of hypertrophic genes (Barry \& Townsend 2010), as shown in Figure 2.

\section{Wnt signalling}

Several studies have shown the involvement of Wnt signalling in cardiac hypertrophy. Wnts are highly conserved secreted glycoproteins with 350-400 amino acids. Wnts contain large, cysteine rich domains, and are extensively palmitoylated (Kikuchi et al. 2007). Because of this palmitoylation, the Wnt proteins are hydrophobic, making it difficult to purify Wnts in an active form. Until now, $19 \mathrm{Wnt}$ ligands and ten Frizzled receptors have been identified. The Wnt ligands can be divided into two subclasses: the Wnt1 class, consisting of Wnt 1, 3, 3a, 7a, signals via the canonical or $\beta$-catenin pathway and the Wnt5a class, consisting of Wnt 2, 4, 5a, 5b, 6, 7b and 11, can activate the calcium
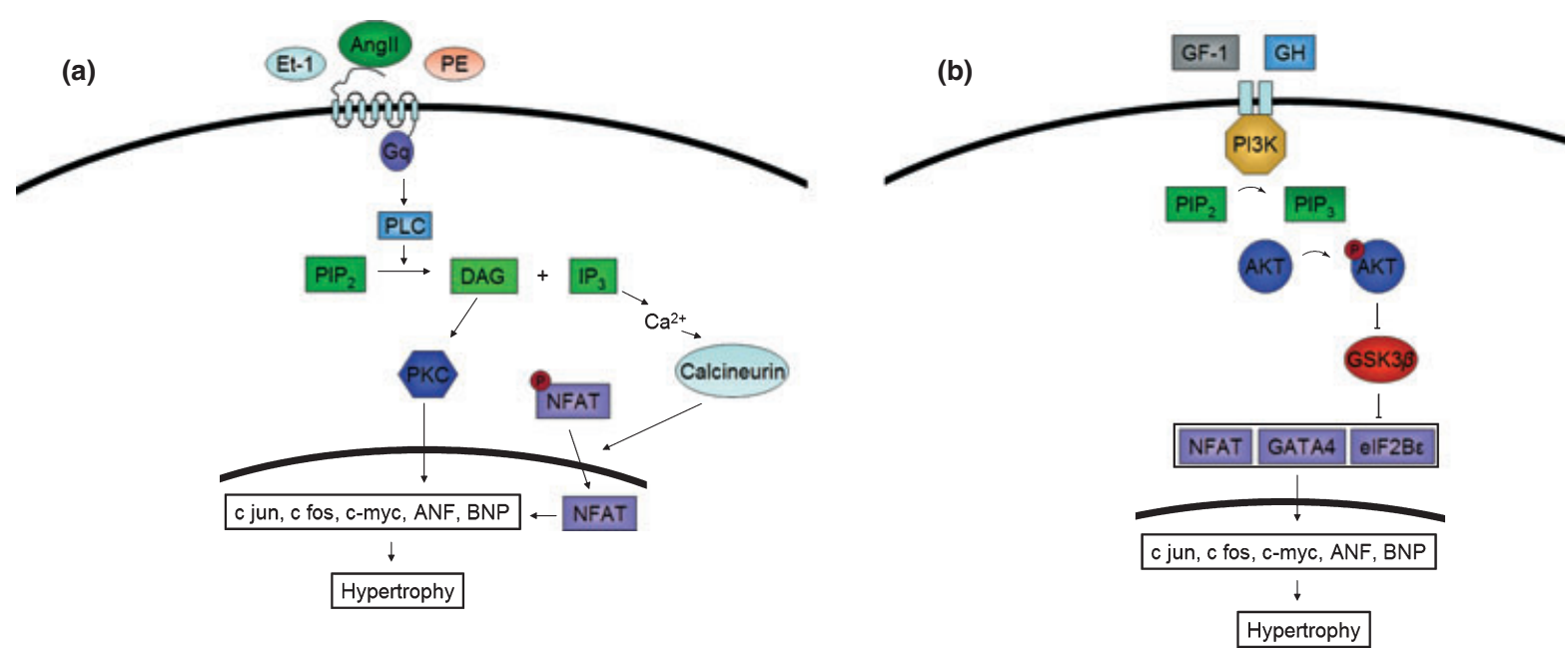

Figure 2 Signalling pathways leading to pathological (a) and physiological hypertrophy (b). In pathological hypertrophy, the stimulation by endothelin-1 (ET-1), Angiotenin II (AngII) or Phenylephrine (PE) lead to activation of Phospholipase-C (PLC) which hydrolyses $\mathrm{PIP}_{2}$ to inositol triphosphate $\left(\mathrm{IP}_{3}\right)$ and diacylglycerol $(\mathrm{DAG}) . \mathrm{IP}_{3}$ then releases intracellular $\mathrm{Ca}^{2+}$, which activates calcineurin. NFAT is dephosphorylated by calcineurin and activates transcription of hypertrophic genes. Dag activates protein kinase C (PKC), which leads to hypertrophic gene transcription. Physiological hypertrophic growth is activated by growth factors as insulin-like growth factor (IGF) and growth hormone (GH). These growth factors activate Phosphoinositide 3' kinase (PI3K) via tyrosine kinase receptors. $\mathrm{PIP}_{2}$ is then phosphorylated to $\mathrm{PIP}_{3}$, which activates Protein kinase B (Akt). The activated Akt phosphorylates glycogen synthase kinase-3 $\beta($ GSK $3 \beta)$ at Ser $^{9}$, which inactivates its kinase activity. In resting cells, activated GSK3 $\beta$ phosphorylates and inhibits a number of transcription factors that are involved in hypertrophy. 
pathway. However, over the last years, it has become clear that such a rigid classification is not correct because several Wnts have been shown to modulate both canonical and non-canonical Wnt signalling. Which pathway is activated depends on the cell type, the receptor, and co-receptor that is involved.

The receptors that bind the Wnt ligands are the seven transmembrane Frizzled receptors. The Frizzled family consists of 10 members. The size of these receptors varies between 500 and 700 amino acids, and the $\mathrm{N}$-terminal part contains a cysteine-rich domain. This domain is the binding site for the Wnt ligand. Several co-receptors for Frizzled have been identified (Hendricks et al. 2008). The lipoprotein receptor-related proteins (LRP) 5 and 6 can act as co-receptor for Frizzled, and provide a binding site for Axin (Cadigan \& Liu 2006).

Three Wnt signalling cascades have been described, namely the $\beta$-catenin, the RhoA/Jnk and the calcium pathway (Fig. 3). The best studied signalling cascade is the $\beta$-catenin-dependent or canonical Wnt signalling pathway. A key molecule in $\beta$-catenin-dependent signalling is glycogen synthase kinase- $3 \beta$ (GSK3 $\beta)$. In the absence of Wnt signalling, GSK3 $\beta$ forms a complex including Axin and adonomatous polypolis coli (APC). This complex is known as the $\beta$-catenin destruction complex. It binds $\beta$-catenin, which is then phosphorylated by GSK $3 \beta$ and casein kinase-1. The phosphorylated $\beta$-catenin is then ubiquitinated and degraded by the proteasome (Kimelman \& Xu 2006), which results in low levels of $\beta$-catenin in the cytoplasm under baseline conditions.

When Wnt signalling is activated by the binding of Wnt to a Frizzled receptor and LRP co-receptor, Dishevelled (Dvl) binds to this Wnt-Frizzled-LRP complex. The Axin-Apc-GSK3 $\beta$ complex is then able to bind to the intracellular domain of LRP, preventing GSK3 $\beta$ to phosphorylate $\beta$-catenin (Cliffe et al. 2003). The $\beta$-catenin then accumulates and is transferred to the nucleus, where it can interact with the transcription factors Tcf/Lef1, and activate the transcription of the target genes, including Cyclin D1 and c-Myc (Cadigan \& Liu 2006).

Wnt can also signal via Jun $\mathrm{N}$-terminal kinase (Jnk) and via calcium. Wnt/Jnk signalling is similar to the planar cell polarity pathway in Drosophila, which regulates the orientation with neighbouring cells of the planar epithelial cells in the wing (Simons \& Mlodzik 2008). Activation by Wnt leads to activation of the GTPases Rac, Cdc42 and Rho, which then activates Jnk and Rho kinase (Rock). Wnt is also able to increase the intracellular $\mathrm{Ca}^{2+}$ concentration and activate calciumdependent signalling via G-proteins. These proteins activate phospholipase-C (PLC). The released $\mathrm{Ca}^{2+}$ activates $\mathrm{Ca}^{2+}$-dependent enzymes, like the calcium/

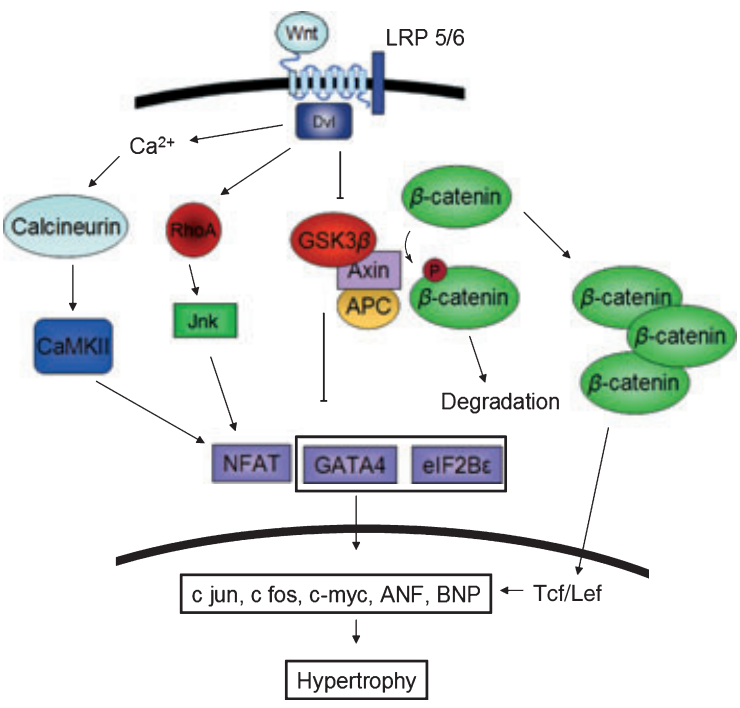

Figure 3 The three different Wnt signalling pathways. In the canonical pathway, activation of Wnt signalling leads to $\beta$-catenin accumulation by the disruption of a complex consisting of glycogen synthase kinase- $3 \beta(\mathrm{GSK} 3 \beta)$, Axin and adenomatous polypolis coli (APC). In absence of Wnt signalling, this complex phosphorylates $\beta$-catenin, which is then degraded. When Wnt signalling is activated, $\beta$-catenin degradation is prevented and $\beta$-catenin can be transferred to the nucleus, where it interacts with the transcription factors Tcf/Lef and initiate transcription. In the Wnt/Jnk pathway, Wnt signalling leads to activation of Rho, which in turn activates jun $\mathrm{N}$-terminal kinase (Jnk) and Rho kinase (Rock). The third Wnt pathway is the $\mathrm{Wnt} / \mathrm{Ca}^{2+}$ pathway. Wnt signalling increases the intracellular $\mathrm{Ca}^{2+}$ concentration. The released $\mathrm{Ca}^{2+}$ activates $\mathrm{Ca}^{2+}$-dependent enzymes, like the calcium/calmodulin-dependent kinase II (CamKII), protein kinase $\mathrm{C}(\mathrm{PKC})$ and calcineurin. Activation of CamKII inhibits the translocation of NFAT to the nucleus in cardiomyocytes by phosphorylation.

calmodulin-dependent kinase II (CamKII), PKC and the phosphatase calcineurin. Activation of CamKII inhibits the translocation of NFAT to the nucleus in cardiomyocytes by phosphorylation (MacDonnell et al. 2009). The activated calcineurin can dephosphorylate NFAT, leading to an accumulation of NFAT in the nucleus (Dejmek et al. 2006), whereas the phosphorylated NFAT is degraded in the cytoplasm.

\section{Antagonists of Wnt signalling}

Several endogenous antagonists of Wnt signalling have been described. Dickkopf (Dkk), which by itself is a target of Wnt signalling, inhibits the formation of a complex of LRP, Frizzled and Wnt (Mao et al. 2002), thereby inhibiting Wnt signalling. Besides this complex formation, interaction of Dkk1 with Kremen is able to internalize the LRP co-receptor, which leads to its degradation (Krishnan et al. 2006). Another class of 
Wnt antagonists are the secreted Frizzled related proteins (sFRPs). These proteins are similar to Frizzled, but lack the transmembrane domain and can scavenge Wnts by competing for binding with the Frizzleds. Also Wnt inhibitory factor (WIF) and Cerberus proteins can bind Wnts and affect the binding to the Frizzled receptors (Krishnan et al. 2006, Bovolenta et al. 2008).

\section{Wnt signalling and cardiac hypertrophy}

During the development of cardiac hypertrophy, several genes are expressed that are also expressed in the developing foetal heart (McMullen \& Jennings 2007, Oka et al. 2007). Wnt signalling is involved in heart development (Bergmann 2010) and therefore this could suggest that Wnt signalling is also activated in cardiac hypertrophy. Several studies showed the involvement of Wnt signalling in cardiac hypertrophy. A study performed in our lab showed the upregulation of Frizzled-2 during the development of cardiac hypertrophy in rat heart tissue after aortic constriction (Blankesteijn et al. 1996). A more extensive micro-array study with three different hypertensive rat models showed a positive correlation between the left ventricular mass and Frizzled-2 mRNA levels and a negative correlation with Dickkopf-3 (Cerutti et al. 2006).

Downstream of Frizzled, expression of Dishevelled (Dvl) was shown to be upregulated after aortic constriction in rats and mice (van de Schans et al. 2007, Malekar et al. 2010). Intervention in Wnt signalling at the level of Dvl can modulate the hypertrophic growth; in our laboratory, we found that in Dvl-1 knockout mice, the hypertrophic response induced by 14 days of thoracic aortic constriction (TAC) was attenuated compared with wild-type mice. Also an increased activity of GSK3 $\beta$, increased AKT phosphorylation and decreased $\beta$-catenin levels were observed (van de Schans et al. 2007, Blankesteijn et al. 2008). In a recent study by Malekar et al., overexpression of Dvl-1 led to hypertrophy, with reduced ejection fraction and increased heart weight. In these mice, the $\beta$-catenin, as well as the Jnk and CamKII, was activated. Depletion of Dvl-1 with siRNAs in cultured cardiomyocytes led to an abrogated response to $\beta$-adrenergic stimulation, suggesting that dishevelled is required and sufficient for $\beta$-adrenergic induced hypertrophy (Malekar et al. 2010). These observations indicate that interventions at the level of Dvl could be a fruitful approach to modulate the hypertrophic response of the heart.

Surprisingly, little is known about the Wnts that are involved in cardiac hypertrophy. We have performed an analysis of the mRNA levels of most of the Wnts in hypertrophic hearts by quantitative PCR, but no upregulation of any of the Wnts was observed (P. ter Horst and W.M. Blankesteijn, unpublished observa- tions). Therefore, it is still unclear which Wnt(s) is/are responsible for the activation of the downstream signalling that takes place in cardiac hypertrophy. However, it has to be noted that these observations should be confirmed by analyses of Wnt protein levels. Unfortunately, this research is hampered by the lack of specific antibodies for most of the Wnt family members.

\section{GSK3 $\beta$}

GSK3 $\beta$ is a Ser/Thr kinase, which plays an important role in canonical/ $\beta$-catenin-dependent Wnt signalling. It was originally identified as a factor regulating glucose metabolism. GSK3 $\beta$ phosphorylates glycogen synthase, which then inhibits its activity. The kinase is catalytically active in resting cells. The activity of the kinase can be inhibited by the phosphorylation of $\mathrm{Ser}^{9}$ residue (Cohen \& Goedert 2004). The phosphorylation of the $\mathrm{Ser}^{9}$ residue occurs by a variety of kinases, including AKT, p60/p85-s6 kinases (S6Ks) and RSKs (Sugden et al. 2008). To phosphorylate a protein, GSK $3 \beta$ requires a priming phosphate group on its target. The phosphorylation of the $\mathrm{Ser}^{9}$ prevents the interaction with this priming phosphate, because GSK3 $\beta$ interacts intramolecularly with the $\mathrm{Ser}^{9}$ phosphate (Dajani et al. 2003). To be active, GSK3 $\beta$ also requires phosphorylation of the $\mathrm{Tyr}^{216}$ residue. This residue is probably phosphorylated by autophosphorylation by GSK3 $\beta$ itself (Cole et al. 2004).

Several studies have shown the involvement of GSK3 $\beta$ in the development of cardiac hypertrophy. Active GSK3 $\beta$ prevents hypertrophic growth by inhibition of transcriptional regulators, such as NFAT, Gata4 and $\operatorname{eIF} 2 \mathrm{~B} \epsilon$. When GSK3 $\beta$ is overexpressed, the development of hypertrophy is attenuated (Michael et al. 2004, Kerkelä et al. 2007). Several hypertrophic stimuli lead to a decreased GSK3 $\beta$ activity. Stimulation by either ET-1 (Haq et al. 2000), $\beta$-adrenoreceptor activation (Morisco et al. 2000) or aortic constriction (Haq et al. 2003) leads to $\mathrm{Ser}^{9}$ phosphorylation and inhibition of GSK3 $\beta$ activity. When the $\operatorname{Ser}^{9}$ residue was replaced by an alanine, the hypertrophic response diminished in response to calcineurin activation, adrenergic stimulation and aortic constriction (Antos et al. 2002). And when GSK3 $\beta$ was inhibited by $\mathrm{LiCl}$, rats developed a higher heart weight, and had increased levels of ANF after abdominal aortic constriction (Tateishi et al. 2010). In human hearts, inhibition of GSK3 $\beta$ was seen in the end-stage of heart failure, but it was not observed in chronic hypertrophy (Haq et al. 2001). Inhibition of GSK3 $\beta$ induced compensated physiological hypertrophy in GSK3 $\beta$-dominant negative mice (Hirotani et al. 2007). These mice had an increased cardiac function, less apoptosis and fibrosis after TAC. 


\section{$\beta$-catenin and hypertrophy}

$\operatorname{GSK} 3 \beta$ is also able to phosphorylate $\beta$-catenin, as part of the $\beta$-catenin degradation complex. $\beta$-catenin has two functions in the cell: it is part of adherens junctions in the catenin/cadherin complex, necessary for cell structure and adhesion, and it serves as a transcription factor. The localization of $\beta$-catenin depends on the phosphorylation of its $\mathrm{Tyr}^{654}$ residue, which leads to complex formation with cadherin and phosphorylation of $\mathrm{Tyr}^{142}$, leading to a decreased affinity for the adhesion complex and migration to the nucleus (Harris \& Peifer 2005).

In cardiomyocytes, $\beta$-catenin levels are increased by the hypertrophic stimuli ET-1 and PE. Overexpression of $\beta$-catenin induced hypertrophic growth of cardiomyocytes (Haq et al. 2003, Hahn et al. 2006). In mutant mice carrying a cardiomyocyte-specific deletion of $\beta$-catenin, the hypertrophic response after TAC was attenuated. In another study also, an attenuated hypertrophic response upon TAC was found in mice haploinsufficient for $\beta$-catenin, but in these mice, the expression of foetal genes was upregulated (Chen et al. 2006, Qu et al. 2007). When $\beta$-catenin is knocked down in cultured cardiomyocytes, they showed attenuated protein synthesis, cell area and inhibition of the upregulation of ANF after treatment with PE. A Lef1 binding site is present in the ANF promoter (Zhang et al. 2009). Treatment with PE as well as inhibition of GSK3 $\beta$ with $\mathrm{LiCl}$ led to the binding of $\beta$-catenin and Lef1 to the ANF promoter. The overexpression of $\beta$-catenin led to an increase in protein synthesis, but was not sufficient to induce the expression of ANF (Zhang et al. 2009); therefore, also other factors play a role.

In contrast to these results, in a study performed by Baurand et al., the cardiomyocyte-specific deletion of $\beta$-catenin increased the hypertrophic response after 2 weeks of AngII infusion. The stabilization of $\beta$-catenin reduced the cardiomyocyte area and ventricular wall thickness at baseline and an abrogated hypertrophic response after AngII infusion (Baurand et al. 2007, Zelarayan et al. 2008). Overall, these observations lead to the conclusion that $\beta$-catenin has the potential to regulate the hypertrophic response upon various stimuli, but there is no clear relationship between $\beta$-catenin levels and the amount of cardiac hypertrophy.

\section{Non-canonical Wnt signalling}

Besides the $\beta$-catenin-dependent Wnt signalling, also other Wnt pathways are involved in cardiac hypertrophy. The activation of Jnk in vitro resulted in a hypertrophic phenotype, in vivo overexpression led to a lethal restrictive cardiomyopathy and induction of foetal gene expression. Inactivation of Jnk stopped the hypertrophic response after pressure overload (Wang 2007).

The $\mathrm{Wnt} / \mathrm{Ca}^{2+}$ pathway is also involved in the hypertrophic response. In human heart failure patients, both calcineurin and NFAT are activated. Their activation was found in pathological but not in physiological hypertrophy (Wilkins et al. 2004). Activation of calcineurin or NFAT induced hypertrophy in mice and the inhibition of calcineurin inhibited the hypertrophic response (Bueno \& Molkentin 2002). In another study, inhibition of both CamKII and calcineurin attenuated the cardiac remodelling (Diedrichs et al. 2004, van Empel \& De Windt 2004). Interestingly, GSK3 $\beta$ is able to counteract the calcineurin activity by phosphorylating NFAT.

At present, it remains unclear what the contribution of non-canonical Wnt signalling to the development of hypertrophy is. Recently, Malekar et al. found that in mice overexpressing Dvl-1, Jnk signalling was enhanced and also CamKII was activated. Additional research is needed to determine the precise role of non-canonical signalling (Malekar et al. 2010).

\section{Wnt signalling and heart failure}

A major problem of cardiac hypertrophy is that it frequently leads to heart failure. Little is known about the role of Wnt/Frizzled signalling in heart failure. In human heart failure patients, decreased Wnt signalling was observed compared with non-failing hearts. The expression of the pro-apoptotic sFRPs-3 and -4 , but not -1 and -2 , were upregulated, and $\beta$-catenin levels were decreased (Schumann et al. 2000). This upregulation of sFRPs -3 and -4 might lead to increased apoptosis and contribute to the transition to heart failure. More studies regarding the expression and function of sFRPs in animal models of heart failure should be performed to get more insight into the role of these sFRPs.

Next to cardiac hypertrophy, myocardial infarction (MI) is one of the main causes of heart failure. It is the result of an occlusion of a coronary artery, leading to cardiac ischaemia and cardiomyocyte death. MI leads to a number of changes in the heart: the workload of the remaining cardiomyocytes increases leading to hypertrophy, dilatation and collagen formation, a process referred to as adverse cardiac remodelling (Sutton \& Sharpe 2000). The infarction leads to inflammation, and the dead cardiomyocytes are replaced by granulation tissue. This granulation tissue eventually matures into a scar (Frangogiannis 2006). When this scar is not properly formed, the ventricles can dilate, which eventually leads to heart failure (van den Borne et al. 2010). In the infarct area, myofibroblasts are present, which are part of granulation tissue. These cells migrate into the infarct, and are thought to counteract the dilatation 
by maintaining the extracellular matrix (van den Borne et al. 2009) (Blankesteijn et al. 2001). A number of studies have shown a role for Wnt signalling in myofibrosblasts. Frizzled-1 and -2 and Dvl-1 are expressed in the area, where the myofibroblasts are migrating after MI (Blankesteijn et al. 1997, Chen et al. 2004). Another study showed the upregulation of Wnt10b, and Frizzled 1,2,5,10 and the downregulation Wnt7b (Barandon et al. 2003). Myofybroblast migration is attenuated by Wnt signalling in a myofibroblast cell line immortalized with telomerase. Migration and differentiation of myofibroblasts are affected by Wnt signalling (Laeremans et al. 2010). Overexpression of FrzA, a sFRP-1 homologue, reduced the infarct size by $50 \%$ after 15 days and the cardiac function was improved. Also, reduced cardiomyocyte apoptosis and increased amount of collagen was observed. The same results could also be obtained in rats by overexpression of $\beta$-catenin in the border zone (Hahn et al. 2006). sFRP2 was upregulated in rat hearts after MI. Injection of sFRP2 into the rat infarct reduced collagen disposition and ventricular fibrosis after 2 weeks, and after 4 weeks, wall-thinning was reduced and the cardiac function was improved (He et al. 2010). In conclusion, Wnt signalling plays a role during the separate phases of infarct healing and Wnt inhibition might have a positive effect on ventricular remodelling after MI.

\section{Wnt signalling as therapeutic target}

Wnt signalling is involved in a variety of processes that are known to modulate the hypertrophic response of the heart. Both $\beta$-catenin-dependent and non- $\beta$-catenindependent pathways are likely to be involved. Wnt signalling can inhibit the GSK $3 \beta$ activity, which inhibits the hypertrophic process. Also, calcineurin is activated by Wnt signalling, which in turn activates NFAT and leads to hypertrophic growth. Modulation of Dvl-1 regulates the hypertrophic growth, both in vitro and in vivo. The Wnt pathway might counteract the ET-1, AngII and PE-induced signalling pathways because GSK3 $\beta$, Jnk and CamKII act upstream of NFAT and other hypertrophy-related transcription factors. Therefore, inhibition of Wnt signalling could be a promising target for anti-hypertrophic therapy, although our knowledge on the interactions of the different pathways is currently limited. Unfortunately, most research has focused so far on the downstream signalling pathways. Only little data are available on signalling at the level of Frizzled and the role of the different Wnt ligands in cardiac hypertrophy.

Most research has been performed on concentric hypertrophy after aortic constriction. Currently, data on the role of Wnt signalling in eccentric or physiological hypertrophy are scarce. Moreover, at present, there are no cardiac-specific ways to block the Wnt pathway. Therefore, research in this area should focus on the Wnts and Frizzleds involved in the hypertrophic response, and study the effect of interventions at the ligand-receptor level on the development of cardiac hypertrophy. This should be accompanied by a search for frizzled antagonists that block the interaction between Wnts and Frizzleds.

\section{Conflict of interest}

The authors declare no conflicts of interest.

\section{References}

Antos, C.L., McKinsey, T.A., Frey, N., Kutschke, W., McAnally, J., Shelton, J., Richardson, J.A., Hill, J.A. \& Olson, E.N. 2002. Activated glycogen synthase- $3 \beta$ suppresses cardiac hypertrophy in vivo. Proc Natl Acad Sci USA 99, 907912.

Barandon, L., Couffinhal, T., Ezan, J., Dufourcq, P., Costet, P., Alzieu, P., Leroux, L., Moreau, C., Dare, D. \& Duplàa, C. 2003. Reduction of infarct size and prevention of cardiac rupture in transgenic mice overexpressing FrzA. Circulation 108, 2282-2289.

Barry, S.P. \& Townsend, P.A. 2010. What causes a broken heart - molecular insights into heart failure. Int Rev Cell Mol Biol 284, 113-179.

Baurand, A., Zelarayan, L., Betney, R., Gehrke, C., Dunger, S., Noack, C., Busjahn, A., Huelsken, J., Taketo, M.M., Birchmeier, W., Dietz, R. \& Bergmann, M.W. 2007. Betacatenin downregulation is required for adaptive cardiac remodeling. Circ Res 100, 1353-1362.

Bergmann, M.W. 2010. Wnt signaling in adult cardiac hypertrophy and remodeling: lessons learned from cardiac development. Circ Res 107, 1198-1208.

Blankesteijn, M.W., Essers-Janssen, Y.P.G., Ulrich, M.M.W. \& Smits, J.F.M. 1996. Increased expression of a homologue of drosophila tissue polarity gene 'frizzled' in left ventricular hypertrophy in the rat, as identified by subtractive hybridization. J Mol Cell Cardiol 28, 1187-1191.

Blankesteijn, W.M., Essers-Janssen, Y.P., Verluyten, M.J., Daemen, M.J. \& Smits, J.F. 1997. A homologue of Drosophila tissue polari0074y gene frizzled is expressed in migrating myofibroblasts in the infarcted rat heart. Nat Med 3, 541-544.

Blankesteijn, W.M., Creemers, E., Lutgens, E., Cleutjens, J.P.M., Daemen, M.J.A.P. \& Smits, J.F.M. 2001. Dynamics of cardiac wound healing following myocardial infarction: observations in genetically altered mice. Acta Physiol Scand 173, 75-82.

Blankesteijn, W.M., van de Schans, V.A., ter Horst, P. \& Smits, J.F. 2008. The Wnt/frizzled/GSK-3b pathway: a novel therapeutic target for cardiac hypertrophy. Trends Pharmacol Sci 29, 175-180.

van den Borne, S.W., van de Schans, V.A., Strzelecka, A.E., Vervoort-Peters, H.T., Lijnen, P.M., Cleutjens, J.P., Smits, J.F., Daemen, M.J., Janssen, B.J. \& Blankesteijn, W.M. 2009. 
Mouse strain determines the outcome of wound healing after myocardial infarction. Cardiovasc Res 84, 273-282.

van den Borne, S.W., Diez, J., Blankesteijn, W.M., Verjans, J., Hofstra, L. \& Narula, J. 2010. Myocardial remodeling after infarction: the role of myofibroblasts. Nat Rev Cardiol 7, 30-37.

Bovolenta, P., Esteve, P., Ruiz, J.M., Cisneros, E. \& LopezRios, J. 2008. Beyond Wnt inhibition: new functions of secreted Frizzled-related proteins in development and disease. J Cell Sci 121, 737-746.

Bueno, O.F. \& Molkentin, J.D. 2002. Involvement of extracellular signal-regulated kinases $1 / 2$ in cardiac hypertrophy and cell death. Circ Res 91, 776-781.

Cadigan, K.M. \& Liu, Y.I. 2006. Wnt signaling: complexity at the surface. J Cell Sci 119, 395-402.

Cerutti, C., Kurdi, M., Bricca, G., Hodroj, W., Paultre, C., Randon, J. \& Gustin, M. 2006. Transcriptional alterations in the left ventricle of three hypertensive rat models. Physiol Genomics 27, 295-308.

Chen, C.M., Strapps, W., Tomlinson, A. \& Struhl, G. 2004. Evidence that the cysteine-rich domain of Drosophila Frizzled family receptors is dispensable for transducing Wingless. Proc Natl Acad Sci USA 101, 15961.

Chen, X., Shevtsov, S.P., Hsich, E., Cui, L., Haq, S., Aronovitz, M., Kerkela, R., Molkentin, J.D., Liao, R., Salomon, R.N., Patten, R. \& Force, T. 2006. The beta-catenin/T-cell factor/ lymphocyte enhancer factor signaling pathway is required for normal and stress-induced cardiac hypertrophy. Mol Cell Biol 26, 4462-4473.

Cliffe, A., Hamada, F. \& Bienz, M. 2003. A role of dishevelled in relocating axin to the plasma membrane during wingless signaling. Curr Biol 13, 960-966.

Cohen, P. \& Goedert, M. 2004. GSK3 inhibitors: development and therapeutic potential. Nat Rev Drug Discov 3, 479-487.

Cole, A., Frame, S. \& Cohen, P. 2004. Further evidence that the tyrosine phosphorylation of glycogen synthase kinase- 3 (GSK3) in mammalian cells is an autophosphorylation event. Biochem J 377, 249-255.

Dajani, R., Fraser, E., Roe, S.M., Yeo, M., Good, V.M., Thompson, V., Dale, T.C. \& Pearl, L.H. 2003. Structural basis for recruitment of glycogen synthase kinase 3 beta to the axin-APC scaffold complex. EMBO J 22, 494-501.

Dejmek, J., Safholm, A., Kamp Nielsen, C., Andersson, T. \& Leandersson, K. 2006. Wnt-5a/Ca2 ${ }^{+}$-induced NFAT activity is counteracted by Wnt-5a/Yes-Cdc42-casein kinase 1-alpha signaling in human mammary epithelial cells. Mol Cell Biol 26, 6024-6036.

Diedrichs, H., Chi, M., Boelck, B., Mehlhorm, U. \& Schwinger, R.H.G. 2004. Increased regulatory activity of the calcineurin/NFAT pathway in human heart failure. Eur J Heart Fail 6, 3-9.

Dorn, G.W. 2007. The fuzzy logic of physiological cardiac hypertrophy. Hypertension 49, 962-970.

Ellery, S., Pakrashi, T., Paul, V. \& Sack, S. 2006. Predicting mortality and rehospitalization in heart failure patients with Home Monitoring. Clin Res Cardiol 95, 29-35.

van Empel, V.P.M. \& De Windt, L.J. 2004. Myocyte hypertrophy and apoptosis: a balancing act. Cardiovasc Res 63, 487-499.
Frangogiannis, N.G. 2006. The mechanistic basis of infarct healing. Antioxid Redox Signal 8, 1907-1939.

Frey, N., Katus, H.A., Olson, E.N. \& Hill, J.A. 2004. Hypertrophy of the heart: a new therapeutic target? $\mathrm{Circu}$ lation 109, 1580-1589.

Hahn, J.-Y., Cho, H.-J., Bae, J.-W., Yuk, H.-S., Kim, K.-i., Park, K.-W., Koo, B.-K., Chae, I.-H., Shin, C.-S., Oh, B.-H., Choi, Y.-S., Park, Y.-B. \& Kim, H.-S. 2006. $\beta$-catenin overexpression reduces myocardial infarct size through differential effects on cardiomyocytes and cardiac fibroblasts. J Biol Chem 281, 30979-30989.

Hannenhalli, S., Putt, M.E., Gilmore, J.M., Wang, J., Parmacek, M.S., Epstein, J.A., Morrisey, E.E., Margulies, K.B. \& Cappola, T.P. 2006. Transcriptional genomics associates fox transcription factors with human heart failure. Circulation 114, 1269-1276.

Haq, S., Choukroun, G., Bin Kang, Z., Ranu, H., Matsui, T., Rosenzweig, A., . Molkentin, J.D., Alessandrini, A., Woodgett, J., Hajjar, R., Michael, A. \& Force, T. 2000. Glycogen synthase kinase-3beta is a negative regulator of cardiomyocyte hypertrophy. J Cell Biol 151, 117-129.

Haq, S., Choukroun, G., Lim, H., Tymitz, K.M., del Monte, F., Gwathmey, J., Grazette, L., Michael, A., Hajjar, R., Force, T. \& Molkentin, J.D. 2001. Differential activation of signal transduction pathways in human hearts with hypertrophy vs. advanced heart failure. Circulation 103, 670-677.

Haq, S., Michael, A., Andreucci, M., Bhattacharya, K., Dotto, P., Walters, B., Woodgett, J., Kilter, H. \& Force, T. 2003. Stabilization of beta-catenin by a Wnt-independent mechanism regulates cardiomyocyte growth. Proc Natl Acad Sci USA 100, 4610-4615.

Harris, T.J.C. \& Peifer, M. 2005. Decisions, decisions: betacatenin chooses between adhesion and transcription. Trends Cell Biol 15, 234-237.

He, W., Zhang, L., Ni, A., Zhang, Z., Mirotsou, M., Mao, L., Pratt, R.E. \& Dzau, V.J. 2010. Exogenously administered secreted frizzled related protein 2 (Sfrp2) reduces fibrosis and improves cardiac function in a rat model of myocardial infarction. Proc Natl Acad Sci USA 107, 21110-21115.

Hendricks, M., Mathuru, A.S., Wang, H., Silander, O., Kee, M.Z.L. \& Jesuthasan, S. 2008. Disruption of Esrom and Ryk identifies the roof plate boundary as an intermediate target for commissure formation. Mol Cell Neurosci 37, 271-283.

Hirotani, S., Zhai, P., Tomita, H., Galeotti, J., Marquez, J.P., Gao, S., Hong, C., Yatani, A., Avila, J. \& Sadoshima, J. 2007. Inhibition of glycogen synthase kinase 3-beta during heart failure is protective. Circ Res 101, 1164-1174.

Kerkelä, R., Woulfe, K. \& Force, T. 2007. Glycogen synthase kinase-3beta - actively inhibiting hypertrophy. Trends Cardiovasc Med 17, 91-96.

Kikuchi, A., Yamamoto, H. \& Kishida, S. 2007. Multiplicity of the interactions of Wnt proteins and their receptors. Cell Signal 19, 659-671.

Kimelman, D. \& Xu, W. 2006. Beta-catenin destruction complex: insights and questions from a structural perspective. Oncogene 25, 7482-7491.

Krishnan, V., Bryant, H.U. \& MacDougald, O.A. 2006. Regulation of bone mass by Wnt signaling. J Clin Invest 116, 1202-1209. 
Laeremans, H., Rensen, S.S., Ottenheijm, H.C.J., Smits, J.F.M. \& Blankesteijn, W.M. 2010. Wnt/frizzled signalling modulates the migration and differentiation of immortalized cardiac fibroblasts. Cardiovasc Res 87, 514-523.

MacDonnell, S.M., Weisser-Thomas, J., Kubo, H., Hanscome, M., Liu, Q., Jaleel, N., Berretta, R., Chen, X., Brown, J.H., Sabri, A.-K., Molkentin, J.D. \& Houser, S.R. 2009. CaMKII negatively regulates calcineurin-NFAT signaling in cardiac myocytes. Circ Res 105, 316-325.

Malekar, P., Hagenmueller, M., Anyanwu, A., Buss, S., Streit, M.R., Weiss, C.S., Wolf, D., Riffel, J., Bauer, A., Katus, H.A. \& Hardt, S.E. 2010. Wnt signaling is critical for maladaptive cardiac hypertrophy and accelerates myocardial remodeling. Hypertension 55, 939-945.

Mao, B., Wu, W., Davidson, G., Marhold, J., Li, M., Mechler, B.M., Delius, H., Hoppe, D., Stannek, P., Walter, C., Glinka, A. \& Niehrs, C. 2002. Kremen proteins are Dickkopf receptors that regulate $\mathrm{Wnt} / \mathrm{beta-catenin}$ signalling. Nature 417, 664-667.

McMullen, J.R. \& Jennings, G.L. 2007. Differences between pathological and physiological cardiac hypertrophy: novel strategies to treat heart failure. Clin Exp Pharmacol Physiol 34, 255-262.

Michael, A., Haq, S., Chen, X., Hsich, E., Cui, L., Walters, B., Shao, Z., Bhattacharya, K., Kilter, H., Huggins, G. et al. 2004. Glycogen synthase kinase-beta regulates growth, calcium homeostasis, and diastolic function in the heart. J Biol Chem 279, 21383-21393.

Morisco, C., Zebrowski, D., Condorelli, G., Tsichlis, P., Vatner, S.F. \& Sadoshima, J. 2000. The Akt-glycogen synthase kinase 3 beta pathway regulates transcription of atrial natriuretic factor induced by beta-adrenergic receptor stimulation in cardiac myocytes. J Biol Chem 275, 14466-14475.

Oka, T., Xu, J. \& Molkentin, J.D. 2007. Re-employment of developmental transcription factors in adult heart disease. Semin Cell Dev Biol 18, 117-131.

Qu, J., Zhou, J., Ping Yi, X., Dong, B., Zheng, H., Miller, L.M., Wang, X., Schneider, M.D. \& Li, F. 2007. Cardiacspecific haploinsufficiency of beta-catenin attenuates cardiac hypertrophy but enhances fetal gene expression in response to aortic constriction. J Mol Cell Cardiol 43, 319-326.

Rohini, A., Agrawal, N., Koyani, C.N. \& Singh, R. 2010. Molecular targets and regulators of cardiac hypertrophy. Pharmacol Res 61, 269-280.

van de Schans, V.A., van den Borne, S.W., Strzelecka, A.E., Janssen, B.J., van der Velden, J.V., Langen, R.C., Wynshaw-
Boris, A., Smits, J.F. \& Blankesteijn, W.M. 2007. Interruption of Wnt signaling attenuates the onset of pressure overload-induced cardiac hypertrophy. Hypertension 49, 473-480.

Schumann, H., Holtz, J., Zerkowski, H.-R. \& Hatzfeld, M. 2000. Expression of secreted frizzled related proteins 3 and 4 in human ventricular myocardium correlates with apoptosis related gene expression. Cardiovasc Res 45, 720-728.

Simons, M. \& Mlodzik, M. 2008. Planar cell polarity signaling: from fly development to human disease. Annu Rev Genet 42, 517-540.

Sugden, P.H., Fuller, S.J., Weiss, S.C. \& Clerk, A. 2008. Glycogen synthase kinase 3 (GSK3) in the heart: a point of integration in hypertrophic signalling and a therapeutic target? A critical analysis. Br J Pharmacol 153, 137-S153.

Sutton, M.G.S.J. \& Sharpe, N. 2000. Left ventricular remodeling after myocardial infarction: pathophysiology and therapy. Circulation 101, 2981-2988.

Tateishi, A., Matsushita, M., Asai, T., Masuda, Z., Kuriyama, M., Kanki, K., Ishino, K., Kawada, M., Sano, S. \& Matsui, H. 2010. Effect of inhibition of glycogen synthase kinase-3 on cardiac hypertrophy during acute pressure overload. Gen Thorac Cardiovasc Surg 58, 265-270.

Usui, S., Yeh, I., Tian, B. \& Sadoshima, J. 2006. Global changes in gene expression during cardiac hypertrophy: A new direction of cardiac signaling research. J Mol Cell Cardiol 41, 219-222.

Wang, Y. 2007. Mitogen-activated protein kinases in heart development and diseases. Circulation 116, 1413-1423.

Wilkins, B.J., Dai, Y.-S., Bueno, O.F., Parsons, S.A., Xu, J., Plank, D.M., Jones, F., Kimball, T.R. \& Molkentin, J.D. 2004. Calcineurin/NFAT coupling participates in pathological, but not physiological, cardiac hypertrophy. Circ Res 94, 110-118.

Zelarayan, L.C., Noack, C., Sekkali, B., Kmecova, J., Gehrke, C., Renger, A., Zafiriou, M.-P., van der Nagel, R., Dietz, R., de Windt, L.J., Balligand, J.-L. \& Bergmann, M.W. 2008. Beta-catenin downregulation attenuates ischemic cardiac remodeling through enhanced resident precursor cell differentiation. Proc Natl Acad Sci USA 105, 1976219767.

Zhang, C.-G., Jia, Z.-Q., Li, B.-H., Zhang, H., Liu, Y.-N., Chen, P., Ma, K.-T. \& Zhou, C.-Y. 2009. Beta-catenin/TCF/ LEF1 can directly regulate phenylephrine-induced cell hypertrophy and Anf transcription in cardiomyocytes. Biochem Biophys Res Commun 390, 258-262. 